\title{
Scale for Measuring Attitude of Farmers towards Sustainable Potato Cultivation in North-East India
}

\author{
Rajib Das* and Kaushal Kumar Jha \\ Department of Agricultural Extension, Nagaland University: SASRD, \\ Medziphema Campus, Nagaland, India \\ *Corresponding author
}

Keywords

Attitude scale, potato farming, sustainability, reliability, validity

Article Info

Accepted: 15 July 2021 Available Online: 10 August 2021
Attitude is considered a psychological construct. It is the way a person views something or trends to behave towards it, often in an evaluative way. Mindset or attitude towards a particular technology or cultivation practice is the key to success in any enterprise. Thus, attitude of farmers play an important role in adoption of sustainable farming. In the present study, a scale was developed to measure the attitude of the farmers towards sustainable potato farming using Likert's summative rating technique. The final scale consists of 21 statements. Split half technique was used to test the reliability of scale. Reliability co-efficient of the scale was found to be 0.72 . Validity of scale was tested using content validity. The reliability and validity of the scale indicated the consistency and precision of the results using the developed scale. The pre tested scale was used for measuring attitude of farmers towards sustainable potato cultivation in north-east India.

\section{Introduction}

Potato is the most important root and tuber crop cultivated worldwide. It is widely grown in more than 125 countries and consumed almost daily by more than a billion people. Potato cultivation is expanding extensively in the developing world, where the potato's ease of cultivation and nutrient content has made it a valuable for attaining food security and cash crop for millions of farmers. After harvest, potatoes can be used for a variety of purposes such as fresh vegetable for cooking, as raw material for making processed food products, food ingredients, starch and alcohol, feed for animals, and seed tubers for growing the next season's crop. Sustainable development of potato farmers in general requires empowerment of small farmers through improved access to production inputs, credit 
and markets. Sustainable agriculture integrates environmental health, economic profitability as well as social and economic equity. The key indicators of sustainability may include fertility management and crop protection, yield level, tuber quality and environmental impact (Pawelzik and Möller, 2014). Fresh produce, grown more sustainably and locally has a positive effect on health and decreases the reliance on costly imported foods. Promotion of local, more sustainable agriculture in North East India has the potential to enhance the food security in a socially and environmentally sustainable way for promoting entrepreneurship.

North-East India consists of eight states namely Arunachal Pradesh, Mizoram, Nagaland, Manipur, Meghalya, Tripura and Sikkim. The, region lies between $21.57^{\circ}$ to $29.30^{\circ}$ North latitude and $89.46^{\circ}$ to $97.30^{\circ}$ East longitude. Almost 9 percent of the area of India lies under NE region, and about 4.5 per cent under population. Approximately 10 per cent of the potato area in India lies in the North-East India. The main reasons for the low potato yields are inadequate availability of important farm inputs like fertilizers, plant protection chemicals, healthy seed and poor management practices, and prevalence of serious diseases like late blight and brown rot, and pests like potato tuber moth and white grubs.

Potato occupies about 21.9 per cent of the total area under vegetable cultivation, having the highest of 28.9 per cent among production of vegetables in India. India ranked third with an area of 18, 28,000 ha, while it ranked second with 3, 43, 91,000 tonnes of production, and ranked at 68th with very low productivity of $181.77 \mathrm{q} / \mathrm{ha}$ only among the potato producing countries. Among the North eastern states, Assam has the highest production of potato followed by Meghalaya and Tripura whereas, Tripura has the highest productivity 17.80 t/ha (NHB, 2018).). Various reasons of biotic and abiotic factors such as lack of HYV seed, rain fed condition, non adoption of recommended package of practices, insects and diseases; lack of infrastructures facilities like cold storage, credit facilities, marketing facilities, etc. hinders the sustainable agricultural production and market development.

Attitude refers to the "degree of positive or negative affect associated with some psychological object', (Thurstone, 1946). "Attitude is considered a psychological construct. It is a mental and emotional entity that would characterize an individual. The success or failure of any agricultural activity depends on the attitude of farmers towards it to a great extent" (Walling \& Jha, 2020). Attitude measurement is a very important factor to be considered especially in research that concerns farmers' socio-economic aspects. It is a fair assumption to say that when farmers are asked to provide information with respect to expenditures on the farm, they tend to exaggerate the costs and expenses. However, when asked about their income, capital and net profits, they become reluctant to deliver actual information. It is therefore immensely important that we evaluate the attitude of farmers in order to avoid such problems of asymmetric information. Understanding of farmer's behaviour with respect to adoption of recommended package of practice is important to enhance the productivity and environmental sustainability to its maximum in addition to keep in concern the necessity of healthy food, healthy people and healthy environment. These research questions motivated the researcher to study the attitude of farmers towards sustainable potato cultivation. Attitude forms one of the most important factors towards sustainability of potato cultivation practices. There are however instances where the researcher is unable to get a completely adequate scale to 
measure a certain concept. Under such circumstances, it becomes necessary to develop a suitable scale which could serve the purpose. No scale is available to measure the attitude of farmers towards sustainable potato farming practices in North-east India. Therefore a research study was undertaken with an objective to develop an attitude scale to measure the attitude of farmers towards sustainable potato farming practices in Northeast India.

\section{Materials and Methods}

"A Likert scale is a unidimensional scale that researchers use to collect respondents' attitudes and opinions. Likert scale is applied as one of the most fundamental and frequently used as psychometric tools in educational and social sciences research" (Joshi et al., 2015). A "Likert scale is the sum of responses to several items. Likert scaling is convenient to work with, for constructing attitude scale, as it makes the response process cumulative. The scores can be summed, yielding a summary score". The method of summated rating suggested by Likert, (1932) was used for construction of the present attitude scale for measuring the attitude of farmers towards sustainable potato cultivation practices, as it offers opportunities to select statements based on their discriminating power as well as being appropriate. The procedures followed for scale construction are as follows:

\section{Item collection}

A group of items which make up an attitude scale is known as a 'Statement'. A statement is anything which is said about a psychological object or stimulus. The initial step in the construction of attitude scale was to collect statements about sustainable potato farming practices. Both favourable and unfavourable statements reflecting various dimensions of attitudes towards sustainable potato cultivation were collected from research papers, newsletters, journals, bulletins, magazines, books and by discussions with professors, subject matter specialists, extension officers and research scientists, who were directly or indirectly exposed to such a system of knowledge.

A preliminary list of 60 statements, consisting of 35 positive and 25 negative statements, capable of differentiating the opinion of farmers towards sustainable potato farming practices were collected based on the applicability of statements to the selected area.

\section{Editing and selection of items}

The statements collected were carefully edited by following the criteria suggested by Edwards, (1957). After rigorous discussions with experts and relevancy test, a total of 46 statements were retained out of 60 statements. Each statement comprised of minimum possible words and these were checked for their easy comprehension. Care was taken to include both positive and negative statements.

\section{Construction of attitude scale}

The attitude scale was developed as by following standard research procedure. A list of statements on sustainable cultivation of potato consisting of 60 items was prepared by using relevant literatures and also by discussing with the subject experts.

To check the relevancy of the 60 items included initially, the test was administered to 25 judges having expertise in the field. The judges were asked to indicate their degree of agreement against each item in three point continuum (MR- Most relevant, R- relevant and LR- less relevant). Out of this 14 items were rated as less relevant by 80 per cent of the judges. Hence these items were discarded from the original list. 


\section{Item analysis}

Item analysis is an important step in the construction of a valid and reliable scale. The purpose of an item analysis is to find those items that form an internally consistent scale and to eliminate from other inconsistent items. 46 statements were subjected to item analysis to delineate the items that discriminate between persons having favorable and unfavorable responses.

The response of respondents for each statements were obtained on a five point continuum ranging from, 'strongly agree', 'agree', 'undecided', 'disagree', and 'strongly disagree' with the scores of $5,4,3,2$, and 1 respectively for positive statements and reverse scoring of $1,2,3,4,5$ for negative statements. The total score for each individual was computed by summing up the scores for all the items.

\section{Computation of ' $t$ ' value}

For computation of $\mathrm{t}$ value, all 46 scale items were administered to a random sample of 20 farmers from non-sampled area. Total scores were obtained for each the respondents based on the sum of the scores of all individual 46 statements on 5 point continuum as stated above. The top 27 per cent of respondents having high total score (high group) and the bottom 27 per cent of the respondents with low score (low group), were used as criterion group to evaluate individual scale items. The critical ratio ( $t$-value) for each item was calculated by using the formula given by Edwards (1957) as follows:

\section{Results and Discussion}

Attitude is the "degree of encouraging or depressing feeling of the farmers towards farming as an occupation. Attitude is a way of thinking, acting or feeling of a person towards a situation or cause. It is the accepted fact that an attitude of an individual plays an important role in determining ones behavior".

Rogers and Shoemaker (1971) explained attitude "as a relatively enduring organization of individual's belief about an object that predisposes his action. Attitude in this study referred to the degree of positive or negative disposition of an individual's towards the recommended selected horticultural crop cultivation practices".

Attitude scale was developed by using Likert (1932) technique with following results:

\section{Selection of attitudinal statements based on critical ratio}

Critical ratio (' $t$ ' value) for all the scale statements was used for final selection of statements. Items or statements were selected on the basis, ' $t$ ' value equal to or greater than 1.75. Statements were arranged in descending order based on their ' $t$ ' values. Finally 21 statements (18 positive and 3 negative) were selected as follows:

\section{Reliability of the scale}

Split-half method was used to determine the reliability of the scale. The two halves were administered randomly to 20 farmers in a nonsampled area. The Pearson product moment correlation between scores of odd and even groups was found to be 0.72 . Thus the scale was found to be reliable.

Spilt half method is considered a convenient method for assessing the reliability of a test due to its advantage of single administration of the test and use of a single sample. The main limitation of Split half method has been that it does not provide the same information as the correlation between two forms given at different times (Cronbach, 1946). This issue 
can however be resolved by using Cronbach's alpha which according to most researchers is the average of all possible split-half correlations (Cortina, 1993).Hence, the standardised version of Cronbach's alpha can be used to get more stability and accuracy with the following formula:

$\alpha$ standardized $=\frac{K r}{[1+(K-1) r]}$

Where, $\mathrm{K}=$ Number of items in scale $\mathrm{r}=$ mean of the $\mathrm{K}(\mathrm{K}-1) / 2$ non-redundant correlation coefficients. The value of Cronbach's alpha was found to be 0.98 , showing that the scale had excellent consistency measurement and thus, the scale was reliable.

\section{Validity of the scale}

It refers to the efficiency with which it measured what it intended to measure. The developed scale was tested for its content validity.

The content validity of scale is sampling adequacy or the representative of the substance, the topics, the matter and the content of a measuring instrument (Kerlinger, 1987). The validity of the scale was examined for content validity by determining how well the content of the scale represented the domain subject matter under study.

The statements of the attitude scale were derived from books, journals, and consultations with concerned experts in the field. The ' $t$ ' values were significant for all the 21 statements indicating high discriminating values. It was inferred that the scores obtained by utilising the present scale would measure the intended items under the present study.
Thus the scale was considered valid based on the content validity criterion.

\section{Administration of scale}

The final scale to measure the attitude of farmers towards sustainable potato cultivation consisted of 21 statements. The scale was administered on a five point continuums viz., strongly agree (SA), agree (A), undecided (UD), disagree (DA) and strongly disagree (SDA) with a score of 5, 4, 3, 2 and 1, respectively for positive statements and reverse scoring for negative statements. Therefore, maximum obtainable score of the respondents based on the present scale is 105 , whereas minimum obtainable score is 21 .

The high or low score of scale connotes the state of attitude of farmers. Respondents were classified in three groups with highly favourable, favourable and low favourable attitude based on mean and standard deviation value of the attitude score.

Attitude is an important measure to determine the favorableness in terms of adoption of innovative cultivation practices. The present study made an endeavour to develop a reliable scale to measure the attitude of farmers towards sustainable potato farming practices in North-east India. Results obtained was helpful to classify the potato farmers in three groups with highly favourable, favourable and low favourable attitude. It will help to provide inputs to the policy makers for incorporating desirable changes in the existing farming system. The reliability and validity of the scale indicated precision and consistency in obtaining the results. Specific target group needs to be addressed with suitable strategies so that sustainable potato farming may be promoted in the North East region of India. 
Table.1

\begin{tabular}{|c|c|c|}
\hline Sr. No. & Statements & t- value \\
\hline 1 & $\begin{array}{c}\text { Sustainable potato farming is a profitable venture as compared to other } \\
\text { farming in the longer run }(+)\end{array}$ & 10.614 \\
\hline 2 & Input requirements are high for sustainable potato farming (-) & 8.552 \\
\hline 3 & Sustainable nutrient management of potato farming increase the cost (-) & 8.222 \\
\hline 4 & Sustainable farming helps in increased economic status of farmers $(+)$ & 6.668 \\
\hline 5 & $\begin{array}{l}\text { Potatoes produced by following sustainable potato farming practices } \\
\text { has better keeping quality than that produced from traditional methods }\end{array}$ & 6.532 \\
\hline 6 & $\begin{array}{l}\text { Sustainable potato farming helps towards generation of farm } \\
\text { employment }(+)\end{array}$ & 6.53 \\
\hline 7 & $\begin{array}{l}\text { A farmer should practice sustainable potato farming as it is helpful in } \\
\text { improvement of microclimate and the ecological balance }(+)\end{array}$ & 6.324 \\
\hline 8 & $\begin{array}{l}\text { Green leaf manuring and green manuring in-situ are advised to enhance } \\
\text { the soil fertility for sustainable potato farming }(+)\end{array}$ & 6 \\
\hline 9 & $\begin{array}{l}\text { Sustainable management of potato pest and disease helps in } \\
\text { maintaining ecological balance }(+)\end{array}$ & 5.902 \\
\hline 10 & $\begin{array}{l}\text { I prefer to participate in soil and water conservation activities in } \\
\text { relation to promote sustainable potato farming }(+)\end{array}$ & 5.715 \\
\hline 11 & $\begin{array}{l}\text { More and more farmers should undertake sustainable potato farming } \\
\text { practices }(+)\end{array}$ & 5.715 \\
\hline 12 & $\begin{array}{l}\text { I feel there is an important reason for judicious use of the resources } \\
\text { like soil, water and vegetation for sustainable potato farming }(+)\end{array}$ & 5.715 \\
\hline 13 & $\begin{array}{l}\text { Sustainable potato farming increases overall production without much } \\
\text { financial burden }(+)\end{array}$ & 5.692 \\
\hline 14 & $\begin{array}{l}\text { Sustainable farming helps to increase farm income for sustainable } \\
\text { livelihood (+) }\end{array}$ & 4.856 \\
\hline 15 & Sustainable farming helps towards a secured occupation $(+)$ & 4.81 \\
\hline 16 & $\begin{array}{l}\text { Incidence of pest and disease attack is considerably reduced in by } \\
\text { following sustainable potato farming practices }(+)\end{array}$ & 4.427 \\
\hline 17 & I go for scientific land management for sustainable potato farming $(+)$ & 4 \\
\hline 18 & $\begin{array}{c}\text { Sustainable potato farming use locally available materials so } \\
\text { management is quite easy }(+)\end{array}$ & 4 \\
\hline 19 & Sustainable potato farming is difficult to practice (-) & 3.779 \\
\hline 20 & $\begin{array}{l}\text { It is preferable to adopt sustainable potato farming practices than } \\
\text { traditional methods }(+)\end{array}$ & 3.465 \\
\hline 21 & $\begin{array}{l}\text { Sustainable potato farming is better in promoting soil and water } \\
\text { conservation measures than the traditional methods }(+)\end{array}$ & 2.449 \\
\hline
\end{tabular}


Fig.1
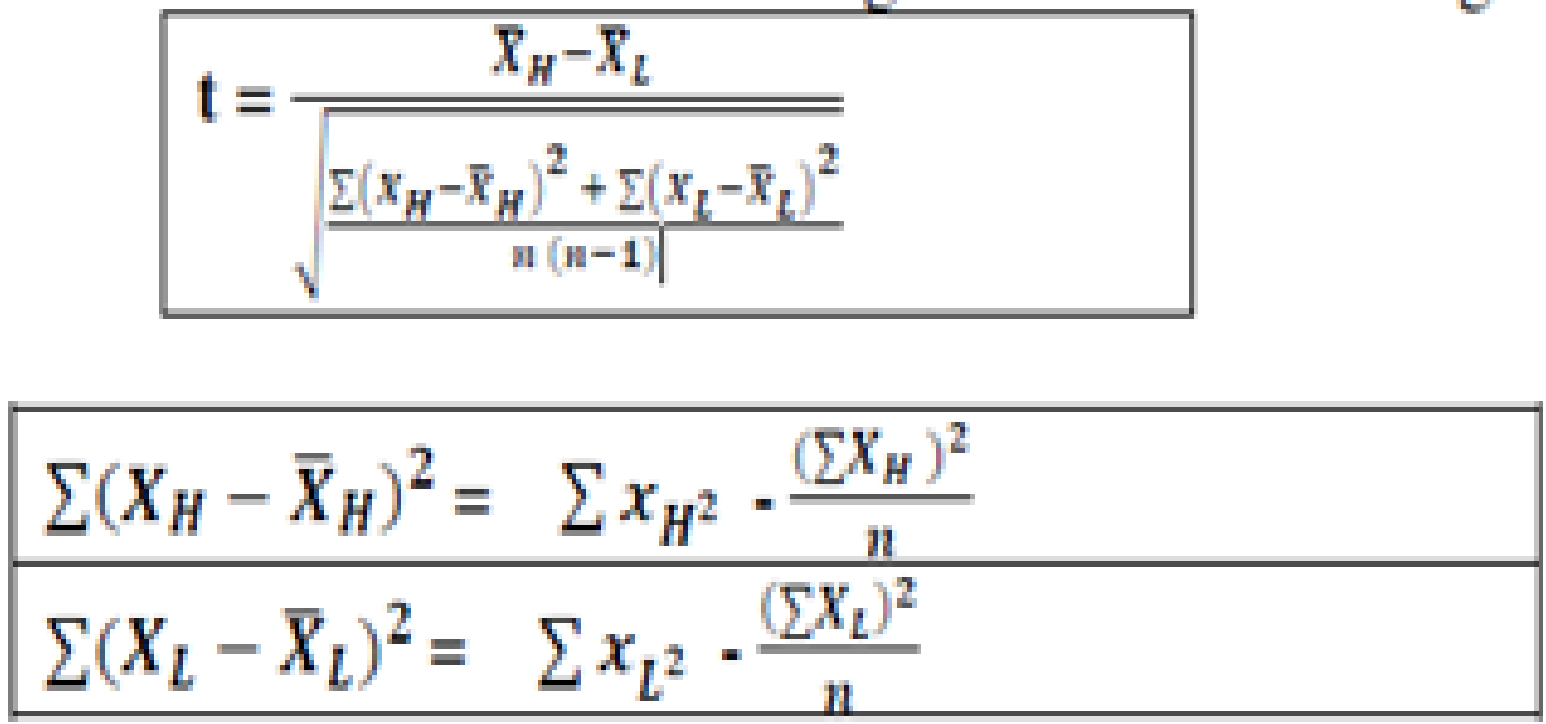

Where

$\bar{X}_{H}=$ Mean score of given statement of high group

$\bar{X}_{L}=$ Mean score of given statement in low group

$\Sigma\left(X_{H}\right)^{2}=$ Sum of squares of individual score on a given statement for high group

$\Sigma\left(X_{L}\right)^{2}=$ Sum of squares of individual score on a given statement for low group

$\sum X_{H}=$ Summation of scores on given statement for high group

$\sum X_{L}=$ Summation of scores on given statement for low group

$\mathrm{n}=$ Number of respondents in each group

\section{Acknowledgement}

The author express his sincere thanks to all farmers of North East India from the states of Tripura, Assam, Nagaland and Meghalaya for their immense co-operation during the research work. Author is highly indebted to Dr. K. K. Jha, Professor \& Head, Department of Agricultural Extension, Nagaland University, SASRD, Medziphema campus, for providing the timely assistance and meticulous guidance for accomplishing the current research work under Ph.D program within the stipulated time framework.

\section{References}

Cortina, J. M. (1993). What is coefficient alpha: An examination of theory and applications. Journal of Applied
Psychology, 78(1): 98-104.

Cronbach, L. J. (1946). A case study of the split-half reliability coefficient. $J$. Educ. Psychol., 37(1): 473-480.

Edwards, A. L. (1957). Techniques of attitude scale construction. Appleton-CenturyCrofts Inc. New York.

Joshi, A., Kale, S., Chandel, S., and Pal, D. (2015). Likert Scale: Explored and Explained. British Journal of Applied Science \& Technology,7: 396-403.

Kerlinger, F. N. (1987). Foundations of behavioral research. (Third Edition). Holt, Rinehart and Winston, New York. Krabbe, P. F. M. (2017). The measurement of health and health status: Concepts, methods and applications from a multidisciplinary perspective. (First Edition). Academic Press. Elsevier, pp.67-89. 
Likert, R. A. (1932). Technique for the measurement of attitude. The science press, New York, 140.

NHB. (2018). Horticultural statistics at a glance. Horticulture Statistics Division Department of Agriculture, Cooperation \& Farmers' Welfare Ministry of Agriculture \& Farmers' Welfare Government of India.

Pawelzik, E. and Möller, K. 2014. Sustainable Potato Production Worldwide: the Challenge to Assess Conventional and
Organic Production Systems. Potato Research, 57:273-290

Rogers, E. M. and Shoemaker, F. F. (1971) Communication of Innovation: A Cross-Cultural Approach. 2nd Edition, The Free Press, New York.

Thurstone, L. L 1946. Comment. American Journal of Sociology, $52: 39-50$.

Walling, K. and Jha, K. K. (2020). Scale for measuring attitude of farmers towards improved large cardamom cultivation. Plant Archives, 20 (2): 4515-4520.

\section{How to cite this article:}

Rajib Das and Kaushal Kumar Jha. 2021. Scale for Measuring Attitude of Farmers Towards Sustainable Potato Cultivation in North-East India. Int.J.Curr.Microbiol.App.Sci. 10(08): 285292. doi: https://doi.org/10.20546/ijcmas.2021.1008.033 